\title{
O meme e a elipse da oração principal em construções temporais com sentido condicional factual
}

\section{The meme and the main clause ellipse in temporal constructions with factual conditional meaning}

\author{
Vanessa Leme Fadel Steinhauser ${ }^{1}$ \\ Juliano Desiderato Antonio ${ }^{2}$
}

\begin{abstract}
Resumo: Com base na abordagem funcionalista, Neves (2011) declara que, nas construções condicionais, pode ocorrer elipse da oração principal, ficando a cargo do interlocutor o preenchimento do conteúdo emoldurado. Partindo dos pressupostos de Neves (2011), de que as construções temporais apresentam particularidades similares às das condicionais, este estudo teve como objetivo, a priori, mostrar que, nas construções temporais, a oração subordinada adverbial temporal também pode vir "isolada", isto é, sem a presença explícita da oração nuclear, principalmente em situações interativas incutidas pela multimodalidade, como ocorre nos memes (Santos, 2018). Posteriormente, o estudo se encarregou de evidenciar o tipo de relação lógico-semântica existente entre a oração adverbial temporal e a imagem. Para tais intentos, 50 memes foram investigados, mas, neste trabalho, são apresentados apenas 6, que, de uma forma geral, ilustram todos os resultados obtidos. A análise constatou que o imbricamento das dimensões verbo-visuais nos memes possibilita a elipse da oração principal em construções temporais, posto que a oração subordinada temporal isolada tem o seu sentido completado (e vice-versa) pela imagem que, nesses casos, representa o conteúdo da oração principal omitida. Ademais, percebeu-se uma relação lógico-semântica temporal com sentido condicional factual em todos os memes analisados.
\end{abstract}

Palavras-chave: Construções temporais. Meme. Multimodalidade. Linguística Funcionalista.

Abstract: Based on the functionalist approach, Neves (2011) states that, in conditional constructions, ellipse of the main clause can occur, leaving the interlocutor to fill in the framed content. From the assumptions of Neves (2011), that the temporal constructions present particularities similar to those of the conditional ones, this study aimed, a priori, to show that, in the temporal constructions, the temporal adverbial subordinate clause can also come "isolated", this is, without the explicit presence of nuclear prayer, mainly in interactive situations instilled by multimodality, as occurs in memes (Santos, 2018). Subsequently, the study was in charge of highlighting the type of logical-semantic relationship between the adverbial temporal clause and the image. For such purposes, 50 memes were investigated, but in this work, only 6 are presented, which, in general, illustrate all the results obtained. The analysis found that the overlapping of the verbal-visual dimensions in memes allows the ellipse of the main sentence in temporal constructions, since the isolated temporal subordinate sentence has its meaning completed (and vice versa) by the image that, in these cases, represents the main sentence content omitted. Furthermore, a temporal-semantic relation with a factual conditional sense was perceived in all the memes analyzed.

Keywords: Temporal constructions. Meme. Multimodality. Functionalist Linguistics.

\footnotetext{
1 Universidade Estadual de Maringá, Programa de Pós-Graduação em Letras, Maringá; Colégio Objetivo, Paranavaí, PR, Brasil. Endereço eletrônico: vanessalemefs@ hotmail.com.

${ }^{2}$ Universidade Estadual de Maringá, Departamento de Teorias Linguísticas e Literárias, Programa de PósGraduação em Letras, Maringá, PR, Brasil. Endereço eletrônico: prof.jdantonio@ gmail.com.
} 


\section{Introdução}

O funcionalismo entende a gramática como suscetível às pressões do uso, pois vê as línguas como instrumentos de comunicação da experiência. A todo momento os interlocutores estão buscando uma comunicação bem-sucedida a partir de suas determinações situacionais e socioculturais, o que faz com que adotem estratégias linguísticas que favoreçam o uso da língua. Nesse viés, percebe-se que a gramática é constantemente determinada pelo uso (Du Bois, 1985), ou seja, está frequentemente a serviço do discurso (Givón, 1979b).

Tomando essas premissas como ponto de partida, este estudo busca provar que, assim como pode ocorrer elipse da oração principal nas construções condicionais (cf. Neves, 2011), nas construções temporais, isso também é possível. Para tal intento, utiliza-se o gênero meme como forma de evidenciar a influência da multimodalidade no comportamento e no uso das construções temporais, dado que, o diálogo verbo-visual existente nos memes permite a oração temporal realizar-se desgarrada da sua principal. Isso pode ser visualizado no exemplo abaixo:

Figura 1: Meme do Scrat

\section{Quando eu vejo comida}

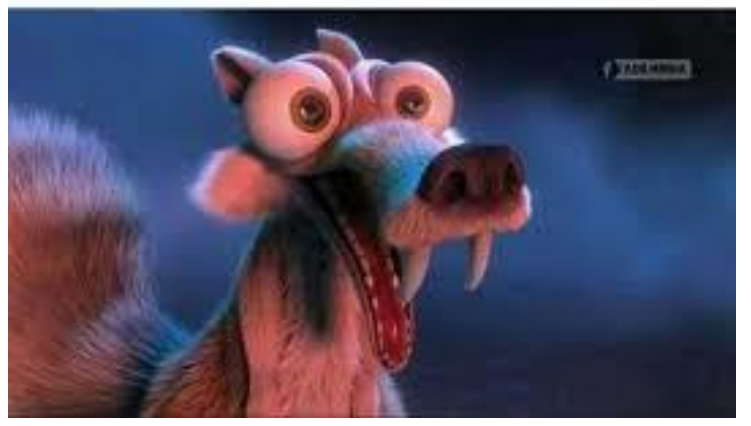

Fonte: Memes e gifs engraçados. Disponível em: https://pt.dopl3r.com/memes/engra\%C3\%A7ado/quando-euvejo-comida-adilhinha/212472. Acesso em: 29 de fev. 2020.

No meme acima, a oração subordinada adverbial temporal "quando eu vejo comida" aparece desacompanhada da oração principal, a qual deveria expressar uma circunstância. Se lida isoladamente, sem a imagem, a oração não pode ser compreendida em sua total amplitude. Contudo, ao ser lida em conjunto com a imagem, percebe-se que as dimensões verbo-visuais se unem para a construção da significação do texto, de modo que fique inteligível.

Essa constatação é bastante relevante, pois mostra que a disposição da construção temporal depende não apenas de fatores gramaticais, mas da situação comunicativa que 
motiva o uso dessas estruturas. Pensando nisso, este estudo adota a Linguística Funcional e a teoria da multimodalidade como embasamentos teóricos para uma análise a qual prevê a descrição de uma particularidade bastante empregada nos memes atualmente, que é a elipse das orações principais em construções temporais.

\section{Pressupostos teóricos}

\section{Linguística Funcional}

O Funcionalismo analisa o funcionamento da língua a partir dos usos socialmente configurados, já que a língua é um instrumento de comunicação verbo-social para os seres humanos. Conforme Cunha (2008, apud MARTELOTTA, 2008, p. 157), o interesse da investigação linguística dos funcionalistas "vai além da estrutura gramatical, buscando na situação comunicativa - que envolve os interlocutores, seus propósitos e o contexto discursivo - a motivação para os fatos da língua".

Há, nesse sentido, toda uma preocupação com o processo de interação entre as motivações internas e externas que, em um jogo de forças (Du Bois, 1985), favorecem diretamente as múltiplas opções de uso que os contextos discursivo-comunicativos projetam. Por conseguinte, a Linguística Funcional se preocupa com a linguagem em uso, compreendendo-a como "recurso para fazer e trocar significados, utilizada no meio social de modo que o indivíduo possa desempenhar papéis sociais" (CABRAL; FUZER, 2014, p. 21). Com base nessas premissas, os funcionalistas entendem que:

A linguagem é uma atividade sócio-cultural; a estrutura serve a funções cognitivas e comunicativas; a estrutura é não-arbitrária, motivada, icônica; mudança e variação estão sempre presentes; o sentido é contextualmente dependente e não-atômico; as categorias não são discretas; a estrutura é maleável e não rígida; as gramáticas são emergentes; as regras de gramática permitem algumas exceções. (KENEDY; MARTELOTTA, 2003, p. 26)

Isto posto, o funcionalismo compreende que "as formas da língua são meios para um fim, não um fim em si mesmas" (HALLIDAY, 1985 apud NEVES, 2018, p. 30), havendo, portanto, uma integração entre os componentes sintático, semântico e pragmáticos na gramática, já que estes são relacionados e interdependentes. Em posição contígua, espera-se assim fazer uma descrição sintática que privilegie uma investigação acerca das circunstâncias discursivas norteadoras das escolhas linguísticas específicas do uso, visto que a abordagem funcionalista almeja explicitar as regularidades visualizadas no uso interativo da língua, verificando as condições discursivas que motivam o uso. 
A partir dessa ótica funcionalista, nota-se que "a estrutura gramatical depende do uso que se faz da língua, ou seja, a estrutura é motivada pela situação comunicativa" (CUNHA; COSTA; CEZÁRIO, 2003, p. 29). Nesse viés, torna-se imprescindível a verificação dos aspectos sintáticos em termos semânticos e pragmáticos, dado que a estrutura gramatical é uma variável dependente às pressões do uso que, por sua vez, moldam o sistema ao longo do tempo. Essa mutabilidade do uso é perceptível principalmente em contextos banhados pela multimodalidade, dado que a mescla de semioses dá origem a novos usos da língua e da linguagem. Com base nessa perspectiva, o próximo tópico discorrerá com mais propriedade sobre a Teoria da Multimodalidade, a qual está de cero modo vinculada ao Funcionalismo.

\section{Teoria da Multimodalidade}

A Era Digital fez com que diversos gêneros ganhassem características multimodais, isto é, mais de um modo de se serem representados. A mescla de recursos semióticos surgiu como estratégia para a produção e o compartilhamento de informações, principalmente nas redes sociais, o que fez com que "imagem e palavra mantivessem uma relação cada vez mais próxima, cada vez mais integrada" (DIONÍSIO, 2005, p. 159), tornando a nossa sociedade cada vez mais visual. Nas palavras de Descardesi (2002), hoje em dia,

[...] qualquer que seja o texto escrito, ele é multi-modal, isto é, composto por mais de um modo de representação. Em uma página, além do código escrito, outras formas de representação como a diagramação da página (layout), a cor e a qualidade do papel, o formato e a cor (ou cores) das letras, a formatação do parágrafo, etc. interferem na mensagem a ser comunicada. Decorre desse postulado teórico que nenhum sinal ou código pode ser entendido ou estudado com sucesso em isolamento, uma vez que se complementam na composição da mensagem. (DESCARDESI, 2002, p. 20)

Essas outras formas de representação que direta ou indiretamente interferem na mensagem transmitida fazem com que a combinação de palavras e imagens tragam implicações discursivas de suma importância para o jogo interacional e conversacional, ainda mais se tratando do universo digital, já que:

Os gêneros discursivos produzem significados e estabelecem relações através dos textos ou discursos neles veiculados. Esses, por sua vez, materializam-se através da linguagem, seja ela verbal ou não-verbal. Todo o arranjo visual existente no gênero, ou seja, a diagramação, cores, figuras, tipo de papel (no caso de texto escrito) ou até como as pessoas se comportam nos textos orais (gestos, entonação de voz, expressões faciais) chamamos de multimodalidade. (FERREIRA; BORTOLUZZI, 2007, p. 1104) 
A teoria da multimodalidade se embasou nos pressupostos da Linguística SistêmicoFuncional (LSF), propostos por Halliday. As metafunções linguísticas de Halliday (1976) foram adotadas para analisar não somente a linguagem escrita ou falada, como também a todos os tipos de semiose humana. Segundo Halliday (1976), os textos se constituem a partir da (i) metafunção interpessoal; (ii) metafunção ideacional; (iii) metafunção textual.

A metafunção interpessoal refere-se “a distinções como as de 'modo' ou 'modalidade' (isto é, as diferenças entre afirmações, perguntas e ordens)" (HALLIDAY, 1976, p. 134). Nessa função, há uma preocupação evidente com a modalidade, ou seja, com o grau de veracidade da mensagem transmitida, posto que a metafunção interpessoal exerce diferentes tipos de relação entre os participantes, sejam eles representados (pessoas, lugares e coisas representadas em imagens) sejam interativos (pessoas que se comunicam com outras por meio de imagens; os produtores e espectadores dessas imagens). Assim sendo, nesse grupo, adotam-se estratégias semióticas que explicitem a realidade social do grupo ao qual a mensagem foi dirigida, de modo a promover a troca interativa entre os participantes e “estabelecer e manter relações sociais para a expressão de papéis sociais, que incluem os papéis comunicativos criados pela própria linguagem” (HALLIDAY, 1976, p. 136).

Já a metafunção ideacional diz respeito "ao que é comumente chamado de 'sentido cognitivo' ou 'conteúdo proposicional' de orações" (HALLIDAY, 1976, p. 134). Nessa função, entende-se que as imagens advêm de estruturas narrativas (processos de ação) e conceituais (processos estáticos), as quais levam em consideração a representação dos seres, dos lugares e das coisas no processo de interação para a construção coesa dos significados. Isso faz com que essa metafunção esteja fortemente vinculada à ideia de "construção de experiências", já que

[...] ao desempenhar tal função, a linguagem também estrutura a experiência e ajuda a determinar nossa maneira de ver as coisas, de modo que exige algum esforço intelectual vê-las de outra maneira que não aquela que nossa linguagem sugere. (HALLIDAY, 1976, p. 136)

Por fim, a metafunção textual é o "modo por que a estrutura gramatical e entonacional das orações as relaciona umas com as outras em textos contínuos e com as situações em que são usadas" (HALLIDAY, 1976, p. 134) por como os falantes de uma língua constroem/organizam o fluxo discursivo da interação, estabelecendo a coesão textual. De acordo com Halliday (1976, p. 137), além de capacitar o falante e o escritor a construir "textos", a função textual "capacita o ouvinte ou o leitor a distinguir um texto de um conjunto 
aleatório de orações" (HALLIDAY, 1976, p. 137). Há, desse modo, a necessidade de se adotar estratégias coerentes que atendam aos propósitos discursivo-comunicativos da mensagem/informação veiculada.

As metafunções de Halliday colaboraram com o desenvolvimento da Gramática do Design Visual (GDV), cujos expoentes são Kress e van Leeuwen. Contudo, com vistas a descrever o modo semiótico visual, na GDV, as metafunções da LSF equivalem-se, respectivamente, a significados interacionais, estruturas representacionais e significados composicionais. Assim, unindo o contexto, a interação, as estratégias discursivas, os produtores e receptores, a GDV espera descrever os sentidos produzidos pela mescla de recursos semióticos nas diferentes situações comunicativas.

Em suma, é válido ressaltar que, na teoria da multimodalidade, as naturezas dos recursos semióticos são "produtos de histórias culturais e recursos cognitivos que usamos para criar significados na produção e interpretação de mensagens visuais e de outros tipos" (JEWITT; OYAMA, 2001, p. 136). A escolha dos recursos semióticos nos atos comunicativos se dá assim pelas motivações que norteiam seu uso, isto é, pelo contexto de produção e recepção das mensagens socialmente constituídas.

Isso prova que a multimodalidade é uma ferramenta extremamente eficiente no processo comunicativo atual, seja em anúncios publicitários, charges, cartazes de filmes, infográficos, seja, até mesmo, nos memes. O sentido gerado pela imbricação da linguagem verbal e da não-verbal favorece múltiplas leituras sobre como os usos estabelecem padrões. Dessa forma, a multimodalidade nos memes acaba por oferecer embasamento teórico para se justificar os fenômenos linguísticos por detrás desse "inocente" gênero discursivo que vem conquistando o mundo - em especial, os brasileiros - que é o meme.

\section{Gênero Meme}

Segundo Santos (2018, p. 1), “como gênero multimodal emergente das redes sociais, o meme constrói sua significação sob uma dupla articulação: a gramática da dimensão linguística e a gramática da dimensão visual". Assim sendo, este é um gênero digital permeado de múltiplas semioses, que pode apresentar tom humorístico ou, ainda, crítico.

Há uma relação bastante intrínseca entre a propagação desse gênero e sua função social. De certo modo, os memes funcionam como replicante cultural (DUARTE, 2014), posto que são ideias, frases, imagens, vídeos, sons, que viralizam rapidamente e se alastram como replicadores linguístico-comportamentais de um contexto sociocultural. 
Para se explicar esse caráter de "replicador" cultural e comportamental, pode-se fazer uma analogia entre o "meme" da internet e o "meme" de Dawkins (um zoólogo darwinista). Segundo esse cientista, assim como os genes podem ser responsáveis pela transmissão e replicação de características às gerações posteriores, existem mecanismos de transmissão cultural e informacional, os quais ele chamou de memes. Para Dawkins (1979), e por extensão Blackmore (1999), os memes podem ser ideias, músicas, histórias, hábitos, invenções, e comportamentos transmitidos por imitação.

À vista disso, Blackmore (1999 apud SOUZA, 2013) entende que as meméticas são "uma força poderosa que moldam nossa evolução, reduzindo o ser humano a uma simples máquina portadora de genes biológicos e de memes culturais, um veículo de disseminação, um ente de quem os replicadores fazem uso para perpetuarem-se pelas gerações”. Essa caráter ora metamórfico (de reinterpretação), ora mimético (de imitação) dos memes de Dawkins pode ser visualizado nos memes da internet, já que também podem ser conceituados como "replicadores comportamentais, unidades de transmissão e de imitação cultural, responsáveis pela propagação de fatos, reprodução de pensamento e comportamento" (SANTOS, 2018, p. 2).

Ao se fazer uma alusão ao meme de Dawkins, os internautas passaram a utilizar o termo "meme" para se referir ao que se espalha na mídia digital, em especial nas redes sociais, já que é no ciberespaço que o compartilhamento de informações se dá de forma mais evidente. Por meio de postagens de fotos e vídeos, comentários, gifs, emojis, figurinhas, os internautas estabelecem relações, fazem inferências e mesclam diversos recursos semióticos com o intuito de se comunicarem e interagirem. Vê-se assim que o uso motiva a escolha de como a informação será transmitida e repercutida.

Com o avanço das tecnologias e dos meios de comunicação, os memes ganharam gosto popular e, hoje, são expressos por textos multimodais que se replicam no meio virtual rapidamente, levando humor, sagacidade e informação aos quatro cantos da internet. Deslocando um enunciado de seu contexto de enunciação, nos memes,

[...] situações acontecidas ou frases ditas em determinados contextos são relacionadas a imagens ou gifs diversos, garantindo nova significação aos Memes, por vezes um tom humorístico. Entretanto, mesmo que muitos vejam os Memes de internet como expressões engraçadas propagadas na Web, a forma de atuação a que foi elevado esse replicante garantiu-lhe um tom crítico, combativo, analítico ou, para ressaltar o contexto brasileiro, de protesto. (SANTOS, 2018, p. 5) 
Isso ilustra o caráter social desse gênero, dado que, além de ser entretenimento, funciona como uma expressão textual (linguística e visual) de grande repercussão em múltiplos contextos e camadas sociais brasileiras. Assim, além de ser um replicador cultural e comportamental, o meme da internet funciona também como um replicador linguístico, posto que, "baseados nos fatos que acontecem na sociedade e que, muitas vezes, ganham grande repercussão na mídia, encerram em si uma efetiva realização linguística em que avultam fatores e construções de cunho lexical, fonético, morfológico e sintático" (SANTOS, 2018, p. $5-6)$.

Com base nessas premissas, o meme é um gênero digital que, por ser multimodal, carrega suas próprias ferramentas de produção e replicação. Unindo imagem e texto em sua composição, humor e crítica no estilo e fatos socioculturais em sua composição temática, esse gênero circula em grande escala no Brasil, tornando-o "o país dos memes".

No gênero supracitado, as dimensões verbal e visual se unem para a construção da significação do texto. Assim, para garantir a compreensão do conteúdo do meme, torna-se viável transpor a mera leitura do componente verbal, e adentar na sintaxe visual, levando em consideração os recursos multimodais que, juntos, dão completude à semântica do texto mêmico. Isso pode ser exemplificado por meio da figura 1, apresentada na introdução deste trabalho, dado que a união da imagem com a frase torna o meme compreensível. Nele, há uma construção temporal formada pela visibilidade da oração temporal e pela elipse da oração principal, a qual tem o seu conteúdo recuperado pela imagem. O próximo tópico traz considerações adicionais sobre as construções temporais e essa possibilidade de elisão.

\section{Construções Temporais}

Segundo Neves (2011), a construção temporal é formada por uma oração principal e uma temporal, a qual pode ser posposta ou anteposta. Isso pode ser visualizado a seguir:

1. Ele acordou quando ela chegou.

2. Quando ela chegou, ele acordou.

A ordem das orações depende do efeito de sentido desejado ou da importância dada pelo produtor do discurso àquela circunstância expressa pela oração temporal. Há, portanto, uma dependência dos fatores semântico-pragmáticos dos elementos numa construção.

Além do "quando", outras conjunções ou locuções conjuntivas podem expressar relação temporal, a exemplo do "enquanto, apenas, mal, antes que, depois que, logo que, assim que, sempre que, até que, desde que, primeiro que, todas as vezes que, cada vez que". 
De fato, cada uma delas traz particularidades muito interessantes para o processo de formação das construções temporais, contudo, nosso estudo está focado em estruturas iniciadas por "quando".

De acordo com Neves (2011), podem-se existir outras relações de tipo lógicosemântico (causal, condicional, concessiva) associadas à relação temporal que se estabelece entre as orações. Tais relações se dão em virtude do conectivo que as ligam e da natureza modo-temporal dos verbos empregados na construção.

[...] a expressão do tempo sempre se liga a relações muito complexas. Essa complexidade aumenta quando a relação temporal envolve dois estados de coisas, isto é, duas predicações, como é exatamente o caso das construções com uma oração principal e uma oração temporal. (NEVES, 2011, p. 795)

Isso pode ser exemplificado pela relação temporal com sentido condicional que ocorre em construções que apresentam simultaneidade, traço não télico e aspecto imperfectivo. A leitura condicional pode se dar quando as orações (subordinada e principal) ocorrem no presente ou no pretérito imperfeito, podendo trazer uma relação simultânea entre o estado de coisas da oração temporal e o da principal (sentido condicional eventual) ou ainda uma relação de simultaneidade tênue, em que o fato expresso na oração temporal é entendido como justificativa para o que se afirma na oração principal (sentido condicional factual). Veja os exemplos abaixo:

3. O bom de ser pobre e feio é que, quando uma pessoa gosta de você, ela gosta mesmo.

4. $\quad \mathrm{O}$ bom de ser pobre e feio é que, se uma pessoa gosta de você, ela gosta mesmo.

Como pode se ver, a relação temporal e a condicional podem estabelecer relações de sentido muito próximas em muitos contextos, o que faz com que determinadas particularidades de uma possam ser observadas na outra também. Embora Neves (2011) não faça menção à possibilidade de elipse da oração principal em construções temporais, pode-se adotar essa ideia se comparada à explicação dada pela autora sobre esse mesmo fenômeno nas construções condicionais, já que, em alguns casos, o uso do conectivo "quando" e do "se" comportam características muito similares. Sobre a elipse, a autora declara que

Nas construções condicionais pode ocorrer elipse da oração principal. Nesses casos, o falante constitui a moldura de referência condicional, que é a oração com SE, mas deixa a cargo do ouvinte o preenchimento do conteúdo emoldurado (a oração principal). O conteúdo da parte nuclear da construção, então, tem de ser resgatado pelo ouvinte segundo seu conhecimento, sua experiência no assunto, ou mesmo, seu desejo. (NEVES, 2011, p. 855) 
A seguir, apresentam-se exemplos de construções em que há elipse da oração principal:

5. Se o prefeito te ouve acusando o filho dele...

6. Ainda se fosse só isso...

7. Ah, se eu fosse solteiro!

Todas essas sentenças são perfeitamente possíveis de serem encontradas na fala. E isso se dá em virtude do conteúdo emoldurado da oração principal ser preenchido pelo ouvinte por meio de seu conhecimento de mundo, de sua experiência no assunto, ou ainda, de seu desejo.

Pensando nas particularidades das construções temporais, os seguintes questionamentos podem ser levantados: pode haver elipse da oração principal em construções temporais? Quais são os contextos comunicativos que propiciam isso? Quais são as relações de tipo lógico-semântico existentes? Para responder a essas perguntas, parte-se agora para a metodologia.

\section{Corpus e metodologia}

Este estudo optou por uma metodologia tipológica de investigação teóricoespeculativa, de natureza qualitativa, que assume uma perspectiva interpretativista de condução, já que busca entender, analisar e interpretar fenômenos inseridos em um contexto (BORTONI-RICARDO, 2008). Adotando um paradigma pós-positivista de investigação, fezse uso do realismo crítico para desenvolver um estudo funcionalista que abarcasse a influência da multimodalidade no uso dos fenômenos linguísticos. Para tanto, foram utilizados principalmente os pressupostos teóricos de Santos (2018) e Neves (2011).

Com vistas a se provar que pode haver elipse da oração principal em construções temporais que apareçam em contextos multimodais, metodologicamente, foram selecionados 50 memes que, apesar de não estarem em número volumoso, podem demonstrar funcionalmente o imbricamento do meio verbal e do visual na significação da mensagem produzida por memes da internet. Como forma de obter esse corpus, utilizou-se a ferramenta de pesquisa "Google Imagens" para encontrar memes que apresentassem construções temporais iniciadas por "quando" e desprovidas visivelmente da oração principal.

\section{Análise dos dados}

Quanto ao aspecto composicional, os 50 memes analisados estruturam-se basicamente do mesmo modo, id est, são compostos por imagens que vêm acompanhadas de uma oração 
subordinada adverbial temporal introduzida por "quando" e isolada, sem a presença explícita da oração principal. Isso pode ser visualizado no meme a seguir:

Figura 2: Meme da Branca de Neve

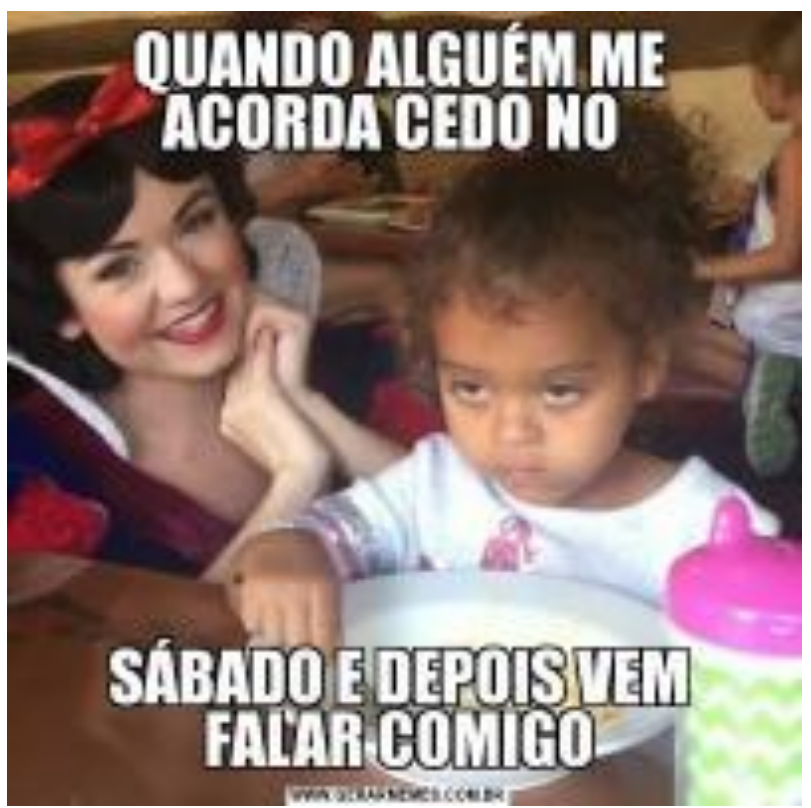

Fonte: Branca de Neve e menina feliz. Disponível em: https://www.gerarmemes.com.br/memes-galeria/530branca-de-neve-menina-feliz/44. Acesso em: 29 fev. 2020.

Acima, vê-se que, por meio da feição da garotinha mediante a presença de uma mulher fantasiada de Branca de Neve, o enunciador dessa mensagem quis retratar a sua reação quando alguém o acorda cedo no sábado e depois vai falar com ele. A cara emburrada da menina revela o desprazer do enunciador em ser acordado e incomodado pela manhã.

Essa leitura não seria possível se fosse observado apenas o aspecto verbal, isto é, a oração subordinada adverbial temporal explícita no meme. Um leitor qualquer poderia apresentar dificuldades em compreender o estatuto semântico atribuído à forma textual em análise. Isso se justifica pela potencial subordinação dessas orações que, tradicionalmente, deveriam sintaticamente funcionar como adjuntos adverbiais.

A oração subordinada adverbial temporal "quando alguém me acorda cedo no sábado" apresenta uma lacuna sintático-semântica se lida isoladamente, não podendo ser identificados explicitamente todos os componentes lexicogramaticais da constituinte ideacional, isto é, participantes, processos e circunstâncias do sistema de subordinação.

Em virtude do meme acima deixar a cargo do leitor o preenchimento do conteúdo emoldurado (a oração principal), este precisa ser resgatado a partir da imagem. Assim, para garantir uma maior inteligibilidade desse meme, necessita-se transpor a leitura do componente verbal e descrever também a sua sintaxe visual. 
Essa leitura imbricada dos componentes verbais e visuais ilustram que as lacunas sintático-semânticas verificadas nas orações isoladas se desmancham ao se estabelecer um diálogo com a dimensão visual. Nota-se, portanto, que a completude semântica do texto mêmico se dá pela leitura fundida dos signos verbais e não-verbais, já que o conteúdo da oração principal é substituído pela imagem, fazendo com que esse aspecto multimodal desempenhe uma função linguística de suma importância, inclusive. Como forma de explicitar tais considerações, vê-se um outro meme abaixo:

Figura 3: Meme da Mia Colucci

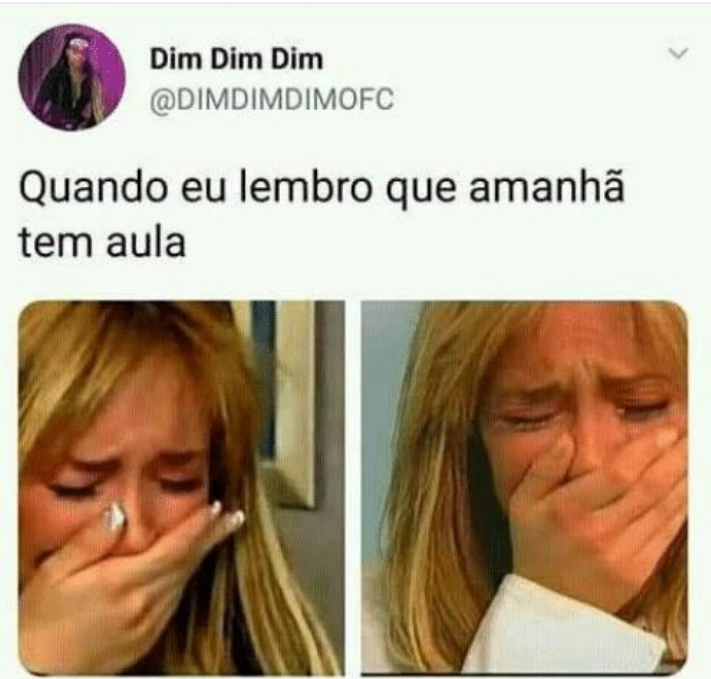

Fonte: Quando eu lembro que amanhã tem aula. Disponível em: https://loveforquotes.com/i/dim-dim-dimdimdimdimofc-quando-eu-lembro-que-amanh\%C3\%A3-tem-e2a2dd3a7a6e4321acae302a0092311d. Acesso em: 29 fev. 2020.

Caso o leitor fosse completar a construção temporal com o preenchimento da oração principal, poderiam surgir algumas possibilidades, como: "quando eu lembro (...), eu fico triste", ou ainda, "quando lembro (...), eu choro". Muitas outras combinações poderiam surgir, porém, todas se caminhariam para uma mesma direção semântica, a infelicidade do interlocutor. Essa interpretação se configura possível mediante o processo representacional que a presença do elemento visual acarreta. A ausência linguística da oração principal não traz danos à compreensão da mensagem transmitida, pois a inteligibilidade é garantida pela leitura das sintaxes verbo-visuais do meme em questão.

Sobre esse diálogo entre os elementos verbo-visuais, Santos (2018, p. 14) declara que o meme é um gênero digital que, "verbalmente, pode ser constituído de uma ou mais orações, estabelecendo um profundo e constante diálogo com a semiose visual". Sua composição sintático-semântica depende, portanto, de uma análise verbo-visual, em que se considere o contexto ao qual o meme se relaciona, id est, "a dinamicidade, informalidade e a 
multiplicidade semiótica próprias da Internet" (SANTOS, 2018, p. 14). Isso pode ser exemplificado com o meme a seguir:

Figura 4: Meme do coelho

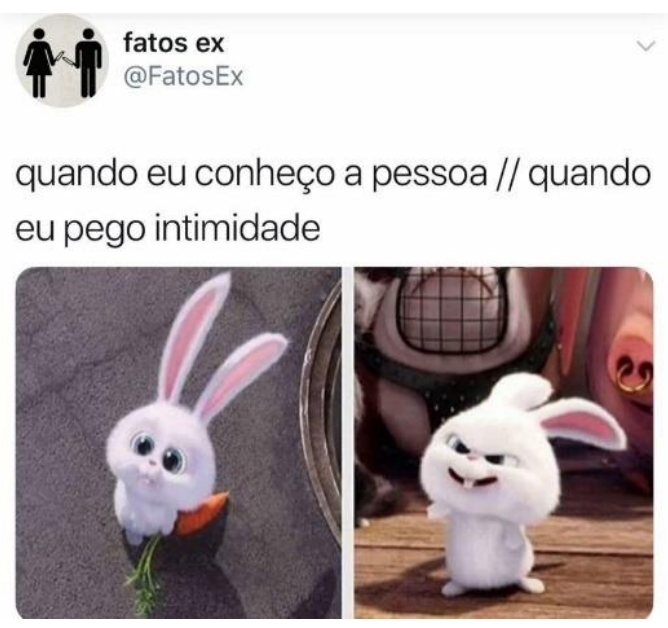

Fonte: Memes engraçados. Disponível em: https://br.pinterest.com/pin/690247080367111113/. Acesso em: 29 fev. 2020.

Para se fazer uma leitura mais atenta desse meme, torna-se viável buscar inferências que propiciem uma ampla compreensão do jogo verbo-visual proposto pelo enunciador. $\mathrm{O}$ sentido é pragmaticamente recuperável com base no diálogo formado entre as orações subordinadas adverbiais temporais e as imagens que funcionam como conteúdo emoldurado para cada uma delas. Porém, desse diálogo, surge o seguinte questionamento: quem teria surgido, isto é, sido pensado primeiro no meme? A imagem ou a escrita (e seu conteúdo temático)?

De antemão, poderíamos pensar que a oração subordinada foi construída primeiro, e a imagem surgiu como um complemento para o sentido da escrita, sendo um mero acessório para a composição do meme, um recurso lúdico e ilustrativo. Caso adotássemos essa hipótese, estaríamos sendo muito superficiais e (talvez) negligentes, pois a imagem possui um conteúdo de força igual ou maior ao apresentado pela escrita.

Por outro lado, se pensarmos que foi a imagem que destoou primeiro, em virtude desta apresentar o conteúdo expresso na oração principal, concluiríamos que a escrita surgiu nesses memes para complementar o sentido da imagem, sendo pensada, portanto, posteriormente. Isso poderia ser comprovado pela própria função sintática exercida pela oração subordinada adverbial temporal, a qual é empregada como um adjunto adverbial, uma moldura de referência para o conteúdo emoldurado na imagem. 
Essa relação de "quem veio primeiro" é muito interessante, pois pode ser justificada não só no âmbito semiótico, mas também no linguístico, já que as funções sintáticosemânticas estão sendo incorporadas tanto nos componentes verbais quanto nos visuais. Veja mais um exemplo de meme que evidencia esse diálogo verbo-visual:

Figura 5: Meme do cachorrinho triste

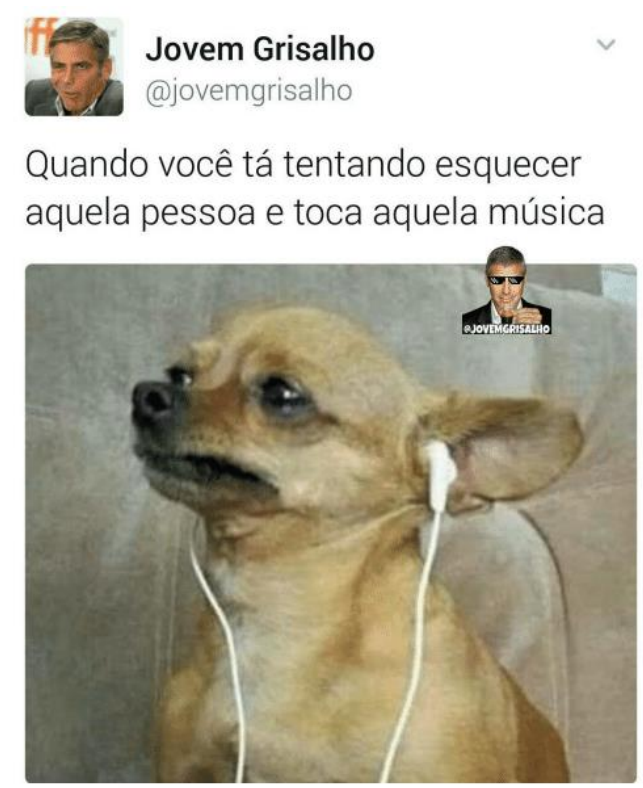

Fonte: Jovem Grisalho. Disponível em: https://me.me/i/jovem-grisalho-ajovemgrisalho-quando-voce-tatentando-esquecer-aquela-pessoa-9293427. Acesso em: 29 fev. 2020.

O meme acima retrata essa ligação intrínseca entre o elemento verbal e o visual, já que o conteúdo semântico existente na imagem do cachorrinho triste com fones de ouvido funciona como um gatilho para o surgimento das orações, em especial, da oração subordinada adverbial temporal "quando você tá", dado que esta funciona como complemento para aquilo que foi sugerido na imagem. Assim sendo, o isolamento da oração temporal no meme se justifica mediante a recuperação do conteúdo semântico emoldurado no elemento visual.

Para finalizar essa primeira análise, a figura 6 traz um meme que, embora o conteúdo da parte nuclear das orações possa ser resgatado pelo leitor conforme seu conhecimento de mundo e/ou sua experiência no assunto - sem a necessidade de um elemento visual, a imagem surge como uma atestadora daquilo que já fora compreendido pelo receptor da mensagem, sendo, assim, um resultado esperado pelo leitor. 
Figura 6: Meme sobre estudar, trabalhar, ter vida pessoal e social

\section{Quando você tenta estudar, trabalhar, ter um namorado, ir a academia, fazer dieta, dormir 8 horas, ficar bem com a sua família e apoiar seus amigos.}

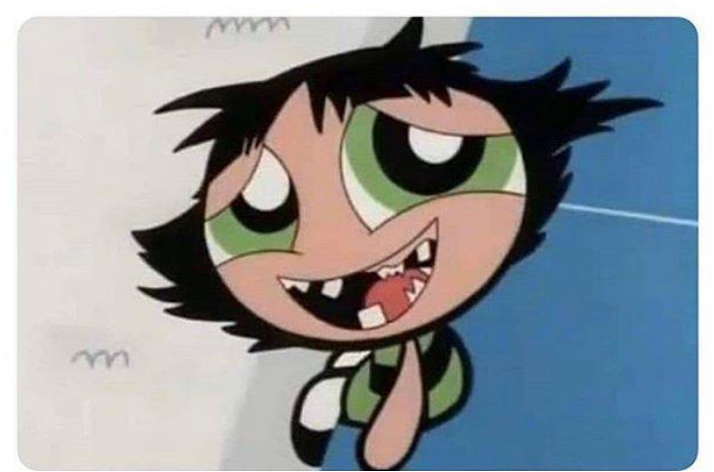

Fonte: Anatomia. Disponível em: https://www.facebook.com/anatomia.love/posts/marque-seus-amigos-vamoscompartilhar-conhecimentossiga-nos-instagramcomsouenfer/1501533323355935/. Acesso em: 29 fev. 2020.

Um outro ponto interessante a ser mencionado sobre esse meme (e todos os outros 49 memes que foram analisados neste estudo - inclusive os acima mencionados) condiz com o tipo de relação lógico-semântica existente entre a oração adverbial e a imagem, a qual representa aqui o conteúdo expresso na oração principal omitida. Com base nisso, o trabalho parte agora em busca da contemplação de seu segundo objetivo, o qual é justamente a verificação de qual relação de tipo lógico-semântico é estabelecida nos memes estudados.

De acordo com Neves (2011), o conectivo "quando" possui um valor neutro, o que o faz apresentar sentidos sobrepostos em alguns casos, mediante dependência modo-temporal. Assim sendo, em todos os 50 memes analisados, deduz-se, com base na citação de Neves (2011), que os verbos da oração nuclear (representada pela imagem) e da oração subordinada moldaram-se no tempo presente. Isso revela que "a correção de presente com presente caracteriza uma perspectiva global imperfectiva de estado de coisas simultâneas (total ou parcial), o que licencia a indicação de habitualidade" (NEVES, 2011, p. 791). Contudo, a relação temporal entre os dois estados de coisas (simultaneidade) nos memes analisados é tênue. A factualidade contida nas orações adverbiais temporais mostram condições preenchidas, isto é, o fato expresso na oração adverbial com sentido condicional pode ser entendido como justificativa para o que se afirma na oração principal. À vista disso, pode-se constatar a presença da relação temporal com sentido condicional factual nos 50 memes analisados do corpus. 
Para se explicar essa complexa relação de tipo lógico-semântico, volta-se novamente aos 6 memes já utilizados como representação neste trabalho, de modo a evidenciar agora a ligação existente entre condição e tempo. De antemão, no meme 1, pode-se fazer uma interpretação condicional da oração temporal "quando eu vejo comida", de modo que essa oração se configure como condição para o fato expresso da imagem. Isto posto, dada a realização/a factualidade da oração temporal com sentido condicional, segue-se, necessariamente, a realização/ a factualidade da oração principal, expressa nos exemplos por meio da imagem. Nesse sentido, pode-se interpretá-la como "quando eu vejo comida (se eu vejo comida), eu fico animado", em que a oração temporal traz essa condição factual para o evento expresso na principal (na imagem).

No meme 2, a oração temporal "quando alguém me acorda cedo no sábado e depois vem falar comigo" também funciona como condição para a realização do fato expresso na imagem, que, no caso, trata-se do semblante irritado da garota. Percebe-se então que a realização do conteúdo expresso pelo componente visual só é possível se dada a factualidade da oração adverbial. Há portanto uma relação factual implicativa que interliga a imagem à escrita, de modo que o fato expresso pela proposição adverbial implica o fato expresso pela oração principal, a qual vem representada pela imagem.

Do mesmo modo, em 3, "quando eu lembro que amanhã tem aula" é, sem sombra de dúvidas, a condição para a menina estar chorando. A combinação do elemento visual e verbal revela que, se dada a realização do fato expresso pela oração adverbial, isto é, se a garota se lembra que tem aula no dia seguinte, tem-se a realização do conteúdo expresso pela figura, isto é, ela fica triste. Essa noção de realização, dá à oração temporal um sentido condicional factual.

No meme 4, vê-se que a forma como o coelho se comporta mediante "a pessoa" é resultado da condição enunciada na oração adverbial, isto é, do fato de ele conhecê-la intimamente ou não. Logo, se o coelho conhece uma nova pessoa, age de maneira "fofa". Contudo, ao passo que vai adquirindo intimidade, mostra sua verdadeira face. Há, portanto, um jogo temporal e condicional bastante evidente nessas relações.

Outrossim, em 5, a tristeza do cachorrinho ao escutar uma música também é efeito da condição expressa na oração adverbial. Por meio de um diálogo multissemiótico, esse meme simboliza uma situação corriqueira na vida das pessoas: a influência das músicas no comportamento e nas emoções humanas.

Por fim, no meme 6, o conteúdo expresso no período "quando você tenta estudar, trabalhar, ter um namorado, ir à academia, fazer dieta, dormir 8 horas, ficar bem com a sua 
família e apoiar seus amigos" pode ser compreendido facilmente como uma moldura de referência para o efeito emoldurado na oração principal (que, no caso, é representado pela imagem). A aparência cansada e desgastada da personagem "Docinho", das Meninas Superpoderosas, surge como representação do efeito causado pelas condições descritas na oração adverbial. O enunciado da oração principal (imagem) é tido como certo, desde que seja dada a realização/a factualidade da oração adverbial temporal com sentido condicional factual.

Além do tipo de relação que se exprime nessas construções temporais, é interessante ressaltar também a forma como a informação no texto foi organizada. A partir dos memes analisados, notou-se que, estruturalmente, a oração adverbial apareceu frequentemente anteposta à imagem, constituindo, em geral, um ponto de apoio para a referência. Parafraseando Neves (2011), pode-se entender então que as orações adverbiais temporais com sentido condicional formam nessas comunicações uma espécie de moldura de referência em relação ao conteúdo expresso pelas imagens.

A partir dessas constatações, vê-se que a disposição/organização da construção temporal depende não apenas dos fatores gramaticais, mas da situação comunicativa que motiva o uso dessas estruturas. Seria duvidoso dizer, portanto, que uma oração subordinada adverbial temporal não possa aparecer isolada em um texto, posto que a visibilidade da oração principal pode ser, como vimos, dependente de fatores que perpassam o campo verbal, adentrando, assim, caminhos que levam para uma semiose visual.

De encontro a essa ideia, seria audacioso dizer também que as construções temporais possuem uma única relação de sentido, já que, a expressão do tempo pode se associar a relações muito complexas. Nos memes aqui estudados, pôde-se constatar que a relação de tipo lógico-semântico condicional pode sim ser lida em uma construção temporal, confirmando que "algumas combinações de predicações com relação temporal efetuadas por quando propiciam leitura condicional, com diferentes nuanças" (NEVES, 2011, p. 797).

De uma forma geral, considerando o corpus de análise, pode-se pressupor que os memes que apresentam elipse da oração principal em construções temporais trariam uma relação de tipo lógico-semântico condicional factual, em que a condição estaria expressa na oração adverbial iniciada por "quando" e o resultado da condição enunciada estaria ilustrado na imagem, a qual detém o conteúdo da oração principal. Isso comprova novamente a intrínseca relação existente entre os elementos verbais e não-verbais no gênero digital multimodal meme e, por extensão, evidencia a influência dessa relação no comportamento dos fenômenos linguísticos. 


\section{Considerações finais}

A completude sintático-semântica proveniente da relação verbo-visual do gênero multimodal meme comprova a influência desse contexto comunicativo no comportamento do fenômeno linguístico estudado. A elipse da oração principal em construções temporais mostrou-se possível nos memes analisados devido ao uso da imagem como representante do conteúdo expresso pela oração principal omitida visivelmente. Isso prova que a completude semântica do texto mêmico se dá pela leitura fundida dos signos verbais e não-verbais.

Ademais, o imbricamento das dimensões verbo-visuais mostrou uma relação temporal com sentido condicional em todos os 50 memes analisados, o que sugere, portanto, que, além de representarem o conteúdo da oração principal, as imagens nesses memes funcionam como efeitos/resultados das condições enunciadas na oração adverbial iniciada pelo conectivo "quando". Os estados de coisas do elemento verbal e do não-verbal dialogam em uma relação de simultaneidade tênue, em que a factualidade expressa pela oração adverbial implica na realização do conteúdo expresso pela oração principal, representada pela imagem). Assim sendo, pode-se sugerir que as orações adverbiais temporais analisadas possuem sentido condicional factual.

Em suma, os dados aqui discutidos mostraram, acima de tudo, que as motivações para os fatos da língua vão além de meras estruturas gramaticais. As vicissitudes dos discursos comunicativos e dos contextos semântico-pragmáticos projetam múltiplas opções de uso da língua, e é exatamente isso que a torna tão rica.

\section{Referências}

BLACKMORE, S. The Meme Machine. Oxford: Oxford University Press, 1999.

BORTONI-RICARDO, S. M. Postulados do paradigma interpretativista. In: BORTONIRICARDO, S. M. O professor pesquisador: introdução à pesquisa qualitativa. São Paulo: Parábola Editorial, 2008.

CABRAL, S. R. S.; FUZER, C. Introdução à gramática sistêmico-funcional em língua Portuguesa. Campinas: Mercado das Letras, 2014.

CUNHA, M. A. F. da; COSTA, M. A; CEZARIO, M. M. Pressupostos teóricos fundamentais. Linguística funcional: teoria e prática. Rio de Janeiro: DP\&A, 2003. p. 29-55.

CUNHA, A. F. Funcionalismo. In: MARTELOTTA, Mário Eduardo (Ed.). Manual de lingüística. Editora Contexto, 2008. p. 157-176.

DAWKINS, R. O gene egoísta. São Paulo: Itatiaia, 1979. 
DESCARDECI, M. A. A. S. Ler o mundo: um olhar através da semiótica social. ETD Educação Temática Digital, v. 3, n. 2, p. 19-26, Campinas: Unicamp, jun.2002.

DIONÍSIO, A. P. Multimodalidade discursiva na atividade oral e escrita. Fala e Escrita. Belo Horizonte: Autêntica, 2005.

DU BOIS, J. W. Competing motivations. In: Iconicity in syntax. Benjamins Amsterdam, 1985.

DUARTE, G. A. No universo especulativo dos memes da copa: a expressão social, consumo e entretenimento na trajetória da seleção brasileira. 4 Encontro de GTS. São Paulo: 2014.

FERREIRA, J. C.; BORTOLUZZI, V. I. Estudos em multimodalidade: A multimodalidade em capas de revista de autoajuda. Anais do, v. 4, 2007.

GIVÓN, T. (Ed.). Discourse and syntax. Academic Pr, 1979.

HALLIDAY, M. A. K. An introduction to functional grammar. Baltimore: E. Arnold, 1985.

HALLIDAY, M. A. K. Estrutura e função da linguagem. In: LYONS, J. (Org.). Novos horizontes em linguística. São Paulo: Cultrix, 1976. p. 134-160.

HALLIDAY, M. A. K. Spoken and written language. Oxford University Press, USA, 1989.

JEWITT, C.; OYAMA, R. Visual meaning: a Social Semiotic approach. In: VAN LEEUWEN, T.; JEWITT, C. Handbook of visual analysis. London, Thousand Oaks, New Delhi: Sage Publications, 2001. p. 134-156.

KENEDY, E; MARTELOTTA, M. E. T. A visão funcionalista da linguagem no século XX. In: CUNHA, M. A. F.; OLIVEIRA, M. R.; MARTELOTTA, M. E. T. (Org.). Linguística Funcional: teoria e prática. Rio de Janeiro: DP\&A / Faperj, 2003, v. 1, p. 17-28.

NEVES, M. H. M. Gramática de Usos do Português. 2. ed. atual. São Paulo: Unesp, 2011.

NEVES, M. H. M. Gramática funcional: interação, discurso e texto. São Paulo: Contexto, 2018.

SANTOS, W. Q. A sintaxe verbo-visual da expressão mêmica no português do Brasil: perspectivas da Linguística Sistêmico-Funcional e da Gramática do Design Visual. In: Anais IX Simpósio Internacional de Estudos de Gêneros textuais. Campinas: Galoá, 2018. v. 1.

SOUZA, C. F. Memes: formações discursivas que ecoam no ciberespaço. Vértices, Campos dos Goytacazes, v. 15, n. 1, p. 127-148, 2013. 


\section{Sobre os autores}

Vanessa Leme Fadel Steinhauser

Mestranda no Programa de Pós-Graduação em Letras da Universidade Estadual de Maringá (UEM); graduada em Letras - Português/Inglês pela Universidade Estadual do Paraná (UNESPAR). É professora de Língua Portuguesa e de Oficina de Produção Textual.

Juliano Desiderato Antonio (Orcid iD: http://orcid.org/0000-0002-9816-5852)

Doutor e mestre em Linguística e Língua Portuguesa pela Universidade Estadual Paulista Júlio de Mesquita Filho (UNESP) - Campus de Araraquara, com pós-doutoramento na UNESP - Campus de São José do Rio Preto; graduado em Letras pela Universidade Estadual de Londrina (UEL). É professor do Departamento de Teorias Linguísticas e Literárias e do Programa de Pós-Graduação em Letras da Universidade Estadual de Maringá (UEM).

Recebido em junho de 2020.

Aprovado em setembro de 2020. 